\title{
ISLAM AND PLURALITY OF SOCIETY IN WEST KALIMANTAN
}

\author{
Zulkifli Abdillah \\ Pontianak State College of Islamic Studies
}

\begin{abstract}
The plurality of the society in West Kalimantan has been formed since the earliest days of the appearance of Islamic style kingdoms or sultanates. However, in its development in the last few decades, the plurality has created social conflicts, especially among Muslims themselves. By using the perspective of normative teachings of Islam and the historicity of its congregants, this paper aims to present the argument that plurality is a thing that must be accepted by anyone as an inevitability.
\end{abstract}

Keywords: Plurality of society, Malay, Dayak.

\section{INTRODUCTION}

The religion of Islam brought by Muhammad as the khataman nabiyyin (Seal of the Prophets) is a religion for all humanity in every time and place, a blessing for all creation. Islam must comply with the conditions of the community with a variety of backgrounds, and be able to answer challenges of the times since it was preached by Muhammad to the present and in the future. Wherever embraced, Islam should be in accordance with local conditions. Thus it is an inevitability that Islam should be able to be applied in all circumstances, including in multiple communities, such as that of West Kalimantan.

The above circumstances cannot always be realized. When Islamic teachings are practiced by its followers, sometimes ideality of Islam begins to suffer from bias. Therefore, in reality Islam sometimes does not describe aspects of ideality above. The religion of Islam, which is supposed to be able to respond to society's challenges and conditions, sometimes is not even capable of facing the people. Many examples may be submitted to illustrate this. Recently, the plurality of the internal thinking of Muslims has sometimes generated a process of mutual blame and physical assault action between groups with different opinions. The cases of the emergence of the sects considered "heretical" which later became widespread became an example of unrealized aspects of ideality of Islam in the practical level. West Kalimantan itself, about a decade ago, also experienced a great social conflict due to the plurality in the community. The sad thing is that, in some cases of social conflicts in West Kalimantan, they involved fellow 
Muslims. The question that arises from this reality is why has Islamic ideality not been able to manifest itself in practical life?

One important thing to note here is that the practice of Islam of course begins with and is based on the results of the reading and understanding of the teachings of Islam. Thus, the cause of the unrealized aspects of the ideality of Islamic teachings in practice lies in the reading and understanding. When Islam does not seem able to deal with the condition of plural society, what needs to be reviewed and corrected is the reading and the understanding of Muslims and other people on the teachings of Islam. In other words, to present Islam as a religion that is able to respond to the challenges and the development of plural society in West Kalimantan, there is a need to fix the reading and understanding of the teachings of Islam.

There are two ways of reading and understanding Islam; first, the normative aspect, namely what is contained in the Quran and Sunnah, and the two aspects of historicity i.e. the practice and behavior of Muslims that have been recorded in the pages of history. This article will review how Islamic teachings see the plurality of a society from both the normative aspects as well as the long journey of the history of Muslims in plural society (a historical perspective). Before discussing these two aspects, the following is a discussion of the plurality of West Kalimantan society that includes various aspects as well as the role and position of Muslims within the plural community.

\section{PLURALITY OF SOCIETY IN WEST KALIMANTAN}

Like other areas in Indonesia, the society of West Kalimantan is plural. The Plurality almost covers all the aspects of life and has been going on since long ago. Viewed from the aspects of ethnicity, it has become common knowledge that West Kalimantan was originally inhabited by people of Dayak and Malay. Later on, immigrants also came from China who was originally employed as a labor contracted by the Sambas and Mempawah Sultanates at the beginning of the 17th century in the field of gold-mining (especially in Monterado and Mandor). According to Syarif Ibrahim Alqadrie (2006) the three groups of this community, Dayak, Malay and Chinese (commonly called Tionghoa in this region), are the three pillars of social, cultural and economic life of the society in West Kalimantan. The life, the progress and the future of this region depend on the very existence of the three ethnic groups. They can be distinguished, but in no way can be separated. In addition to the three major ethnic groups, since hundreds of years ago, other ethnic groups from other regions of the archipelago also came to settle here such as Bugis, Madurese, Banjarese, Arabs, and so forth. One of the factors they were attracted to come 
to West Kalimantan was related to the economic interests, especially trade. The position of West Kalimantan within easy reach due to its strategic location has supported and facilitated the arrival of people from other areas of especially through the ship line.

From the aspect of religion and belief, West Kalimantan is also plural. At first, the Dayak society practiced their original faith, which is called the religion of Kaharingan. In addition, there is some evidence that Hinduism also had influence on a small part of West Kalimantan community. Hindu influence was derived from Majapahit Kingdom during the reign of Hayam Wuruk in Java. In the book Negara Kertagama chapter 13 and 14, it is written that the Kingdoms of Tanjungpura and Sambas were part of the territory of Majapahit (Muljono, 1965: 40). Later on, Islam was brought by the missionary and traders by both domestic and overseas Muslims. In the process, Islam became the official religion of several sultanates/kingdoms. The Pontianak Sultanate, founded by Syarif Abdurrahman Alkadri, a son of the famous cleric Sayid Habib Husein Alkadri, was known as the Islamic Kingdom from the day it was founded. When the Sultanes in West Kalimantan brought the Chinese people to be employed in mining, they also brought their original belief or religion, Confucianism, with them. Later on, the presence of Dutch also brought Christianity to the West Kalimantan region. These two religions were initially embraced by the Chinese people, but later also embraced by the Dayak. Today, particularly in West Kalimantan, the Malay people are identified as Muslims, while the Dayak identified as Catholics. The ethnic Chinese currently enjoy the freedom to embrace and practice the Confucian religion, especially after the wave of reform swept the country. Previously, since the 1960s Confucianism was not allowed to be practiced in Indonesia. The Government of the New Order recognized the Confucian religion only as a sect of Buddhism.

The plurality of the society of West Kalimantan is also reflected in the culture and traditions that develop in the community. There are a variety of ethnic groups settling in West Kalimantan and each has its own culture and tradition. In addition to the culture and traditions of the ethnic groups, there is also a culture or tradition that is partly derived from the teachings of religions. Muslims are known for many ceremonies associated with the cycle of life. The ceremonies, if examined more deeply, seem to adopt elements of the teachings of the Islamic religion blended with the traditions of the community. The attitude of the Muslims themselves are diverse in addressing the culture and traditions, ranging from accepting and preserving, selectively accepting or rejecting and attempting to get rid of them. Thus, plurality is not just a case due to different religions, but it also occurs in a same religion. 
Plurality (lack of Unity) in the religion of Islam itself has existed since after the death of the Messenger of God. Plurality (or split to be precise) among Muslims at first was merely politically motivated. However, it has also penetrated into the realm of religion, theology and law. The phenomenon of the plurality of political views and aspirations among Muslims in West Kalimantan is also quite prominent. In addition to the emergence of Islamic political parties (whether explicitly claiming as Islamic parties or the founder and its constituents are based on the Muslim congregants), the political interests of the Muslim political elites also often cause confusion among the people (particularly Muslims).

\section{THE ROLE AND POSITION OF THE MUSLIMS}

In particular, we must talk about Muslims, not only because of the confusion, but more than that the Muslims must understand the role and position from both religious and sociological point of view. From the religious point of view, the Quran mentions that in addition to being a "servant of God", man is also the "Caliph of God" on Earth. Both roles must run hand in hand, without any emphasis on that one and ignoring the other. As a servant, man should be subject to obey and surrender in the presence of God; and as the Caliph, man should play an active role to keep, maintain, make the most of the Earth and its contents. The tasks of the human being as the Caliph are to establish and maintain relations between fellow human beings (with their plurality) so as to create peace, serenity, happiness and prosperity. The Quran specifically mentions that Muslims are the ummatan wasathan:

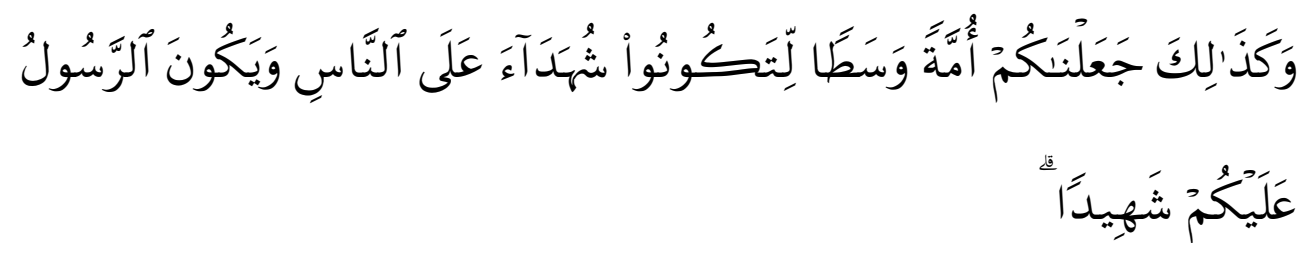

"And thus we have made you a just community that you will be witnesses over the people and the Messenger will be a witness over you." (Q.S. Al-Baqarah 2: 143).

The ummatan wasathan is a moderate ummah whose position is in the middle, so that it is seen by all sides and from all directions. They are made so - according to verse above - in order become martyrs (witnesses), as well as being a role model and patron for others, and at the same time they made the Prophet Muhammad as an example and witness patron for all their activities. Wasathiyat (moderation or middle position) invites Muslims to interact, to have dialogs, and to be open to all parties (religion, culture, and civilization), 
because they cannot bear witness or justice if they close themselves from their environment global development (Shihab, 1996: 328-329). In that strategic position, Muslims should be showing Islam as a mercy for all the worlds.

From the sociological point of view, Muslims as part of West Kalimantan society should be the creator, maintainer and guardian of the harmonious relations between fellow members of the community. As the majority, Muslims must play their strategic role among other people. The plurality of West Kalimantan society should become a potential for building a more civilized community.

The ideal role and position of Muslims above will be meaningful if it can be realized. The issue is an understanding of the role and strategic position has yet to be realized to its full potential. One of the reasons is confusion in understanding and addressing the existing the plurality of a society. To better understand it, there are at least two perspectives that can be used: first, the normative perspective (revelation) and second, the historical perspective. Normatively, there are many verses in the Quran that talk about plurality of a society as well as guidance on how it should address such matters. The norms of the Quran have further been practiced by Muslims in the course of history since the time of the Prophet until today. In historical perspective, it cannot be denied that not all Muslims are able to apply the norms that exist in the Quran or the Sunnah. However, there are many Muslims in the past that had provided the best example of how to address plurality that existed in the community. The following section will put forth some of the norms of the Quran as well as the past experience of Muslims in addressing plurality of a society.

\section{PLURALITY: QURANIC PERSPECTIVE}

We often assume that our nation is unique when compared to other nations in the world. The uniqueness lies in the plurality of its people. This assumption is actually incorrect because it is very difficult to find a society that is truly homogeneous, unfragmented, without any elements of difference in it. In the Qur'an it is said that plurality in the community is sunnatullah:

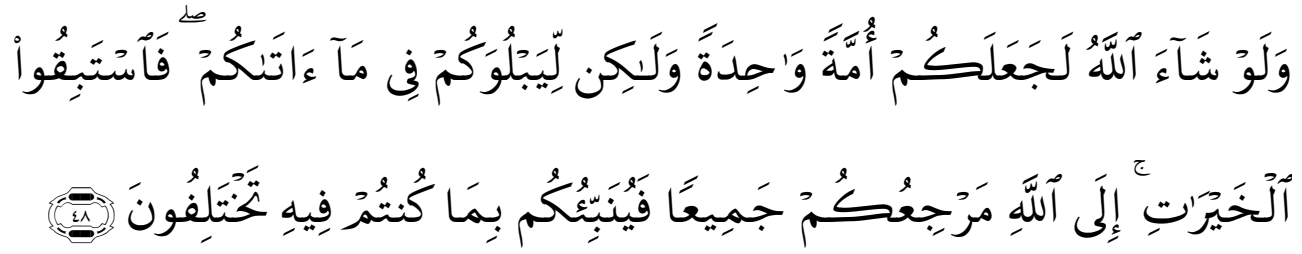

“... Had Allah willed, He would have made you one nation, but He intended to test you in what He has given you; so race to all that is good. To Allah is your return all together, and He will then inform you concerning that over which you 
used to differ." (Q.S. al-Maidah 5: 48).

Plurality is indeed desired by Allah. Plurality is not an issue if addressed correctly. Plurality of mankind is revealed as a test. The difference is created in order to be utilized by human beings as a medium to do virtues. With different people, it is expected that there will be a healthy rivalry between groups competing to do good; not otherwise (e.g. blaming each other and considering one's own group the most correct while the other groups are all wrong).

In another verse, Allah reiterates that man is created not only with different sexes, but also with different tribes and nations in order to know each other:

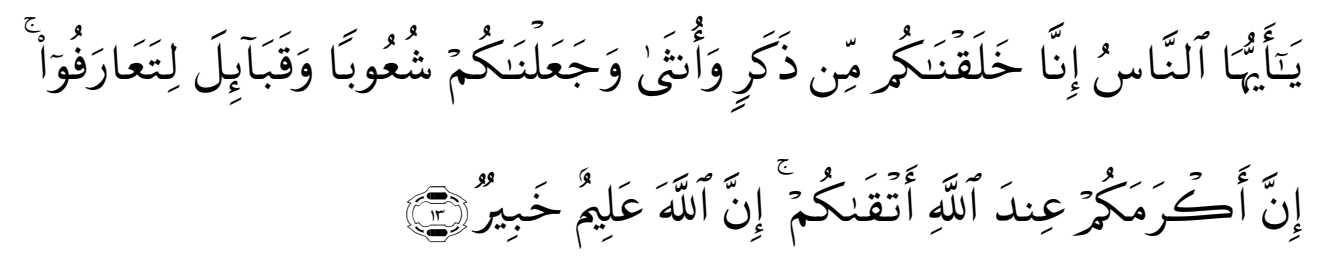

"O mankind, indeed We have created you from male and female and made you peoples and tribes that you may know one another. Indeed, the most noble of you in the sight of Allah is the most righteous of you. Indeed, Allah is Knowing and Acquainted." (Q.S. al-Hujurat 49: 13).

Thus it can be said that, according to the Quran, human beings are social creatures, and by nature social life is an inevitability for them.

The level of intelligence, ability, and social status of man according to the Quran also vary:

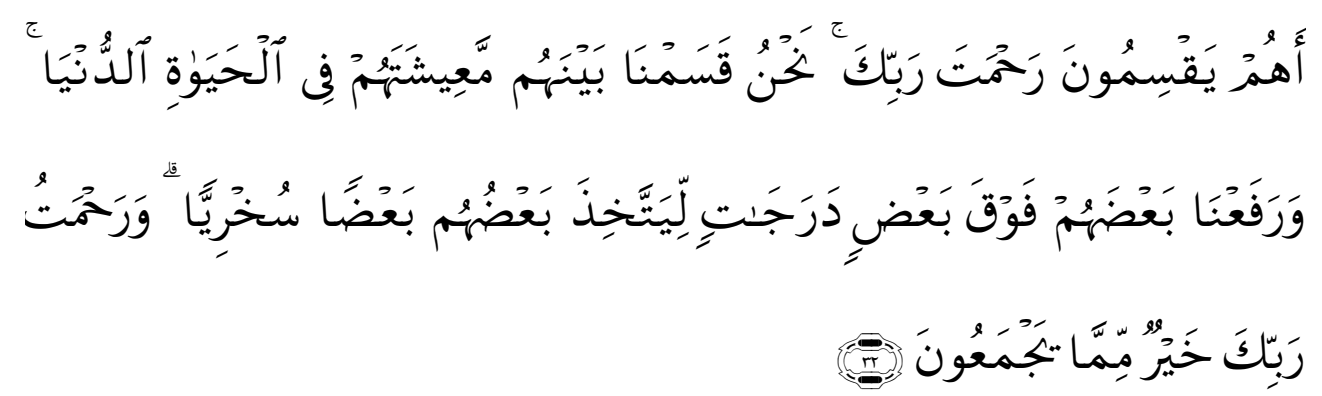

"Do they distribute the mercy of your Lord? It is We who have apportioned among them their livelihood in the life of this world and have raised some of them above others in degrees [of rank] that they may make use of one another for service. But the mercy of your Lord is better than whatever they accumulate." (Q.S. Al-Zukhruf 43:32).

As shown from the above verse, such differences aim to make people help each other (some of them could benefit from some others) and thus all need 
each other and tend to relate to others. This verse also stresses that society is something that is born from each human's natural instinct (Shihab, 1996: 320). More practically/technically, the Quran gives a guidance to behave in social life:

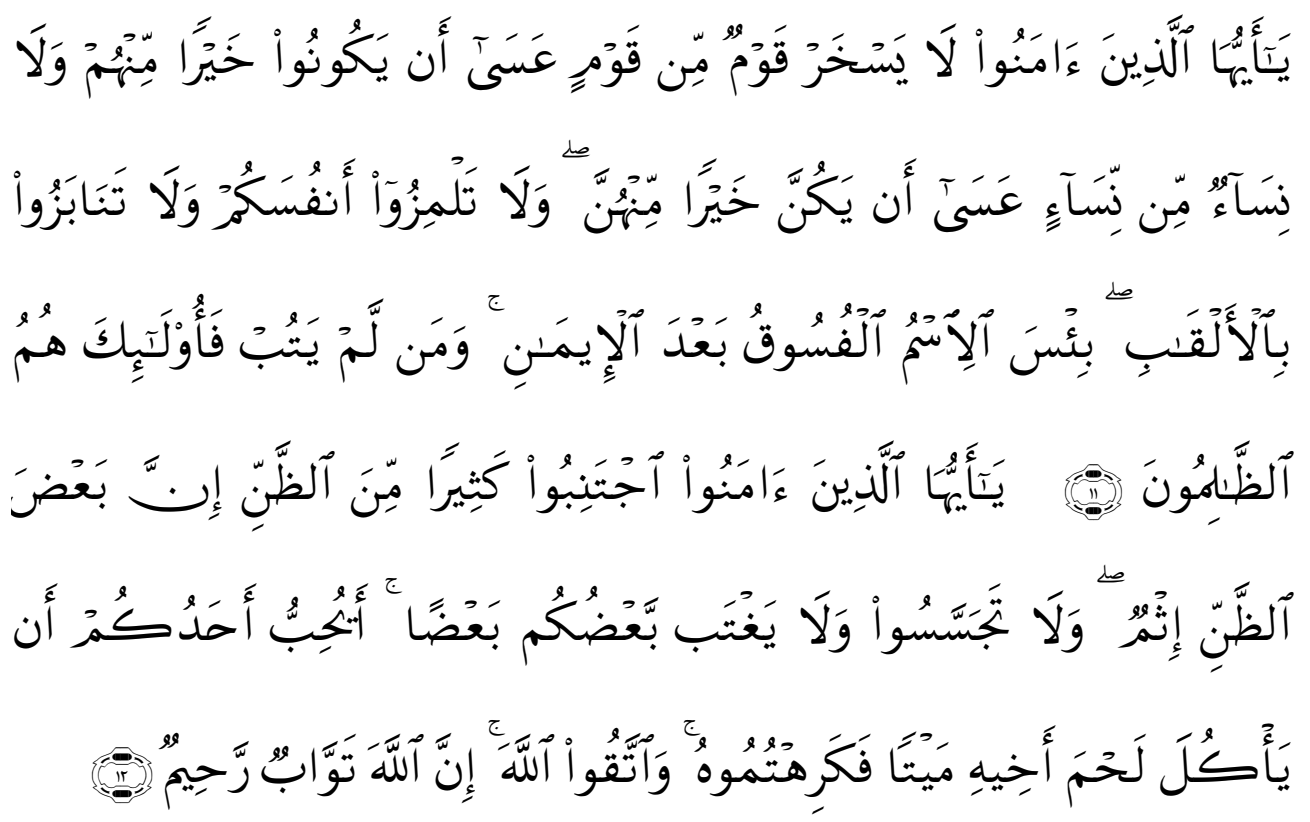

"O believers, let not a people ridicule another people; perhaps they may be better than them; nor let women ridicule other women; perhaps they may be better than them. And do not insult one another and do not call each other by [offensive] nicknames. Wretched is the name of disobedience after [one's] faith. And whoever does not repent - then it is those who are the wrongdoers. O believers, avoid much negative assumption. Indeed, some assumption is sin. And do not spy or backbite each other. Would one of you like to eat the flesh of his brother when dead? You would detest it. And fear Allah; indeed, Allah is Accepting of repentance and Merciful."(Q.S. Al-Hujurat 49: 11-12).

The second verse above expressly states social life guidance. The guidance is the prohibition to: (1) disdain each other, (2) denounce each other, (3) call each other a bad name, (4) assume each other negatively, (5) find fault in others, and (6) backbite each other. The guidance of the Quran is reinforced by the following Hadith of the Prophet:

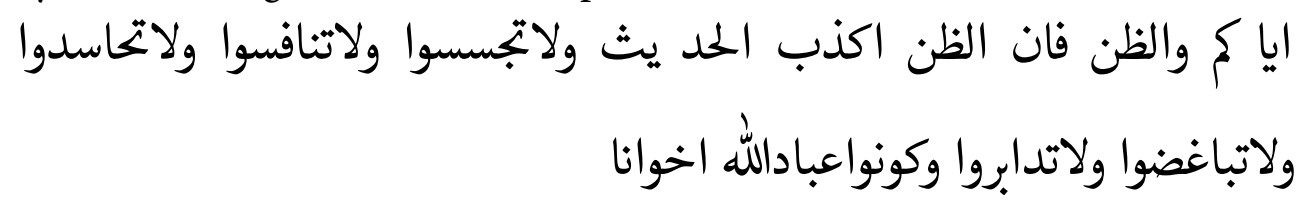


"Avoid negative assumption, because it is the worst lie. Don't find fault in each other. Don't be jealous of each other, don't turn your back at each other" (narrated by the six scholars of Hadith, except An-Nasa'i, through Abu Hurairah).

The guidance of the Quran and the Hadith is very appropriate to be applied in West Kalimantan due to its plural society. As the Quran is revealed not only for Muslims but also as a guide for all humans, this guidance must be socialized to the rest of the community, whatever their background. Plurality in West Kalimantan actually will not cause problems such as social conflict if all parties can implement the guidance of the Quran.

Related to the plurality of religion and belief, the Quran also states expressly and clearly that:

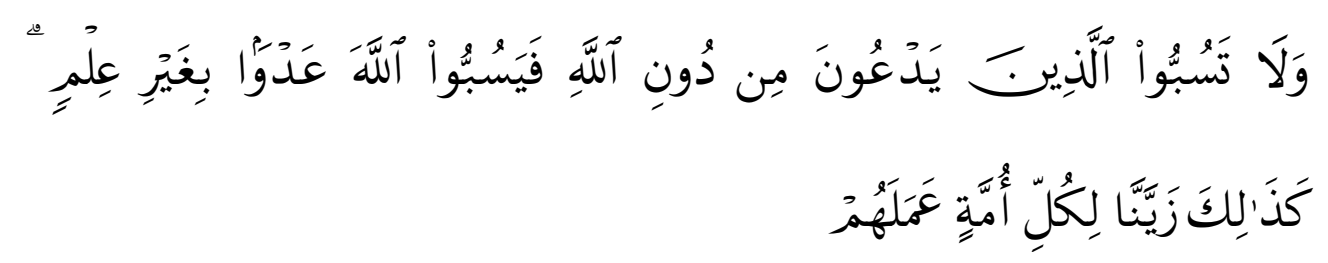

"And do not insult those they invoke other than Allah, lest they insult Allah in enmity without knowledge. Thus We have made pleasing to every community their deeds.... " (Q.S. Al-An'am 6: 108).

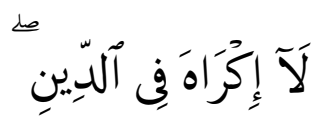

“There is no compulsion to (embrace) religion (Islam)” (Q.S. Al-Baqarah 2: 256).

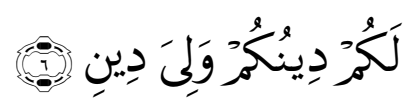

"For you is your religion, and for me is my religion" (Q.S. Al-Kafirun 109:6)

The last verse above is very popular, but unfortunately not everyone is able to understand and apply it in social life. This verse is the main basic Islamic teachings about religious tolerance. In addition to having the meaning of tolerance between people of different religious traditions, this verse can also be interpreted as internal religious tolerance. It means in the face of the various understandings of Muslims over religion that gives rise to various schools or groups, all Muslims must be able to demonstrate the attitude of tolerance toward people who disagree with certain groups.

In the face of plurality of religion and belief, everyone should have a humble attitude and the willingness that besides the truth that he believes, there is another truth believed by others. There should be no coercion that all men 
must be of the same faith (believe in what do). Isn't it God's will that makes some people disbelieve?

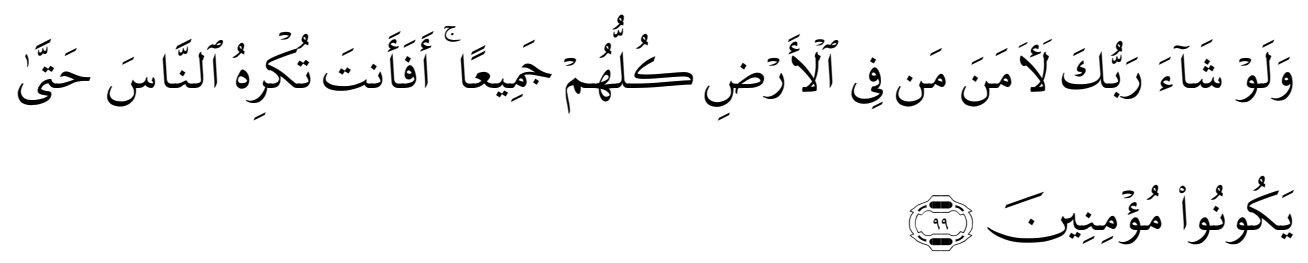

"And had your Lord willed, those on earth would have believed - all of them entirely. Then, [O Muhammad], would you compel the people in order that they become believers?" (Q.S. Yunus 10: 99).

\section{ISLAM AND PLURALITY OF SOCIETY IN THE PATH OF HISTORY}

To understand what attitude Muslims should have regarding the plurality of a society is very important to uncover the history of the long history of Muslims. It is based on the understanding that what has been practiced by Muslims in the path of history is an embodiment of their understanding of Islamic teachings. What is practiced by Muslims in a long span of time and in a wide area is actually the result of a blend between normative values and Islamic customs and traditions. As mentioned above, not all that happened in the history of the Muslim Ummah is good and can be set as an example. There are things and events that we do not have to follow, because they do not comply with the normative values of Islam. The following are some events or important things in the history of the Muslims that can be a decent role model in dealing with and addressing the plurality of a society, particularly in West Kalimantan.

After preaching in Mecca without success and even expelled by the infidels of Mecca, the Prophet then went to Yatsrib (Medina). While the community in Mecca was relatively homogeneous, in Medina the Prophet dealt with multiple communities, both in terms of the tribe and the religion/belief. According to Engineer (1999: 145) Medina at that time was at least inhabited by approximately eleven groups that could be called clans. Three clans embraced the Jewish religion, while eight clans were Arabs. Mubarakfury (1997: 239) mentions that the people of Medina when Muhammad migrated there consisted of three groups of believers, each differing greatly from each other, namely: (1) his noble and good friends; (2) the polytheists who absolutely refused to believe in him, who came from various tribes, and (3) the Jews. Meanwhile, Hasan (2001: 187-188) divides the community of Medina into three groups, namely the Muhajirin, Ansor and Jews. One of the strategies 
adopted by the Prophet to deal with the plural community of Medina was to bind them in a treaty that was written by Prophet Muhammad himself. The Treaty was later known as the Charter or Constitution of Medina.

In the Charter the Messenger of God stated that the Quraish Muhajirin and the Yatsrib belong to one ummah. A number of the clan names were mentioned in the Charter, namely Bani Auf, Bani Saidah, Bani Al-Harts, Bani AnNajjar, Bani Amr bin Auf, Bani Al-Aus. They were allowed to remain in their traditions that as long as they comply with Islam. Some of the Jewish clans were also mentioned, namely the Jews of Bani Auf, the Jews of Bani An-Najjar, the Jews of Bani Auf, the Jews of Bani Al-Harits, the Jews of Bani Saidah, the Jews of Bani Jusyam, the Jews of Bani Al-Aus, the Jews of Bani Tsa'labah, dan the Jews of Bani Suthaibah. Jews from a variety of clans had equal rights. If the Jews followed the Messenger of Allah (Islam), they were entitled to assistance, togetherness, and not to be defeated. The Jews were free to practice their religion and the Muslim could practice theirs. Those bound by this agreement (the clans mentioned) were obliged to provide help (defense) against anyone who intended to attack Yatsrib (Medina). Pagan groups (polytheists) were also mentioned in this agreement. They should not protect the property of Quraishi people or their souls and may not confront the believers.

If the entire contents of the Charter are carefully reviewed, we will find that the Messenger of Allah, peace be upon him: (1) managed to unite the Muslims even though they came from different tribes; (2) managed to improve cooperation and loyalty among each individual; (3) managed to impart awareness to Muslims that the congregants belonged to one group with equal rights and common religious and political views. Among those rights was the right to security; any perpetrators of damage would be punished; and (4) managed to implement equal rights for the Jews regarding public interest and to open the door for those who converted to Islam and protect their rights (Hasan, 2001: 190-191).

The agreement made by the Prophet as the Foundation to build a "state" of Medina has important things to note. The communities of Medina, both in terms of ethnicity and belief, could be united into one ummah because there was a certainty of law (i.e. the agreement made the Messenger). In addition to the existence of the law, the quality of the leadership of the Prophet became the dominant factor in uniting the community of Medina. They even accepted the Prophet willingly since they had waited for a leader who could resolve the conflicts that frequently occurred in the community.

The next path of the history of Muslims that needs to get serious attention related to the plurality of community was during the reign of Abbasiyah 
caliphate and Islam in Spain. During the Abbasiyah dynasty, an Islamic political power was already so widespread. During this period, Islam was not only influenced by the Arab culture, but also by cultures outside the Arabs. The rise of intellectuality during the Abbasiyah Caliphate according to Philip K Hitti (2006: 381) is largely due to the inclusion of foreign influence, such as that of the Indo-Persian and Syrian, and more importantly the Greek. In Syria, they absorbed Aramaic civilization that had been there before, that had been influenced by Greece, and in Iraq they also adopted a similar civilization having been influenced by the Persians. The same thing is also expressed by Badri Yatim (2006: 56) who asserts that the progress of civilization (especially science) reached its peak during the Abbasiyah Caliphate, among others, was caused by the assimilation between the Arabs and other peoples who first experienced the developments in the field of science. During the Abbasiyah Caliphate, the many non-Arab peoples converted to Islam. Assimilation took place effectively. Those peoples provided contribution in the development of science in Islam. The Persian influence was very strong in the area of governance. In addition, the Persians contributed to the development of science, philosophy, and literature. The influence of India can be seen in the fields of medicine, mathematics, and astronomy. Meanwhile the influence of Greece went through translations in many fields of science, especially the philosophy.

At the same time with the progress achieved by the Abbasiyah dynasty, in another Islamic world i.e. in Andalusia (Spain) the progress of civilization also reached the highest peak. The progress of Islam in Andalusia should be recognized by all parties as one of the chains of transmission of world civilization to achieve the shape it is today in the Western world. The progress of the Western world was influenced the progress of the civilization of Islam in Andalusia. The community Islamis Spain was a pluralist society, comprising various religious and tribal communities. With religious tolerance, these communities could work together and gave contributed the development. Religious tolerance was guaranteed by the authorities to Christians and Jews, so they could take part in establishing the Islamic civilization in Spain. The Christians and the Jews were provided special judges to deal with the issues in accordance with the teachings of their religion respective religions (Yatim, 2006: 106).

While there was fierce competition between the Abbasiyah in Baghdad and the Umayyah dynasty in Spain, the cultural relations of the East and the West was not always in the form of warfare. Since the 11th century onwards, many scholars travel from the western end of the Islamic region to the far east, 
bringing with them books and ideas. This indicates that, although Muslims were split in some political views, there is cultural unity of the Islamic world. The political schism in the Muluk al-Thawa' if and thereafter did not cause the decline of civilization. In fact, it was the culmination of advances in science, art, and culture of the Islamic Spain (Yatim, 2006: 1006).

The peaks of Islamic civilization during the Abbasiyah and Umayyah in Andalusia mentioned above give an idea that the plurality of community can serve as a driving factor for the progress of civilization centered on the progress of science. Plurality maintained by authoritative leaders and accompanied by democratic political conditions and tolerance will produce a high civilization. Even when political conditions are not conducive, the development of civilization will continue to take place when the community has realized the importance of science as a core of the progress of civilization. Political differences and territorial boundaries should not be a barrier for the development of science.

How about the Indonesian community, particularly in the West Kalimantan? To see the plurality of the society in West Kalimantan in the past and attitude of the Muslims at the time, the author will discuss the plurality of the community in the Sultanate of Pontianak. In addition limited sources of reference, this selection is based on the fact that the Sultanate of Pontianak was founded by Muslims and since the beginning of its foundation the Sultanate has been characterized by Islam.

The Sultanate of Pontianak was founded by Syarif Abdrurrahman by setting a strategic place to build new settlements (the area around the present day Kadriyah Palace). The work first performed by Syarif Abd ar-Rahman and his followers was to open and clear the land that had been selected beforehand. In preparing land for settlements, Syarif Abdurrahman, assisted by his followers (among others comprising the Bengalis) as well as the local people (i.e. Dayak and Malay). Before Syarif Abdurrahman and his followers arrived at the area, it had been inhabited by the Dayak and Malay. The arrival of Syarif Abdurrahman was well received by locals and they even assisted in preparing the first settlement land for him. In further development, Syarif Abdurahman granted agricultural land to the Dayak people who wanted to live along the Kapuas River and Landak River. Most of them was interested in embracing Islam and became loyal followers of Syarif Abdurrahman (Rahman, et. al., 2000: 73-78). The Dayak people, according to Lontaan (1975: 235) came gradually as many as five groups with a total of 320 families.

The selection of the strategic location made Pontianak thrive. People from different areas come to Pontianak to conduct trade. Most of them settled in 
this area. No wonder some villages are named according to the inhabitants' area of origin, such as Banjar, Kampung Serasan, Bali, Dalam Bugis, Tambelan-Sampit, Siantan (see Hasanuddin \& Kristanto, 2001: 68). Based on a poem written by the Matan Sultan on July 7, 1895 (27 Muharram $1336 \mathrm{H}$ ), it is mentioned that the residents of Pontianak were plural if viewed from ethnic or regional origins. Pontianak in 1895 was inhabited by Europeans (the Dutch, English, etc), Bugis (from Wajo and Sumbawa), people from Java (Betawi, Surabaya, etc), Bali, Madura (Sumenep, Bawean), Malay, from Borneo (Banjarmasin, Banjarnegara, Martapura, Banjar Tanggi, Brunei, Sarawak, Singkawang, Sambas), from the Riau Islands (Tambelan, Jemaja, Bunguran, Siantan, Serasan, Daik, Lingga, Munto, Belitung), from Sumatra (Batu Bara, Siak, Bengkulu, Padang, Deli, Kampar, Kuantan, Jambi, Palembang), from Malaysia (Pulau Pinang, Melaka, Johor, Pahang, Singapore, Trengganu, Kelantan, Patani), from Indochina (Cambodia), from Sulawesi (Bugis, Makassar, Buton), Sumbawa, from the Arab Peninsula (Hadralmaut), from Africa [Habsi, Walkiti Arab (Egypt)], from India (Keling, Surati), and the Chinese (Arena Wati, 1989: 92-94; 147-149). The poem also mentions that socio-culturally Pontianak residents also had diverse livelihood (farming or gardening, trading, labor, small enterprises, prostitution), culture (the Chinese Toapekong party), religions (Muslims and Non-Muslims).

The plurality of the society in Pontianak as described above has provided a positive contribution to the development of the city/Sultanate. The area surrounding the Palace was inhabited and developed by relatives of the Sultan, consisting of people of Arab descent, Bugis and Malay. Siantan area was formerly developed as trade areas by the Chinese under the leadership of Lo Fang (Hasanuddin \& Kristanto, 2001: 70). The area of Sungai Ambawang was originally developed by the Dayak who were mostly farmers. When the political power of the Dutch expended to include Pontianak, the Sultanate and the Dutch signed an agreement to provide the Dutch with an area in the Southern part of the Kapuas River. This provision, known as the Tanah Seribu or Verkendepall was an area of 1000x1000 square meters. This area was central to the development of the city administration which drew the attention of the Chinese to settle and develop it as a commercial center (currently Gajahmada area) as offices and settlements were constructed. According to Hasanuddin \& Kristanto (2001: 71) the settlement policy was part of the management strategies and the cultural boundary between different ethnic groups and associated also with the division of employment so as to prevent inter-ethnic conflict or disputes. The policies adopted by the Sultanate in the past is clearly no longer possible to apply in the city of Pontianak today. 


\section{CONCLUSION}

As already mentioned, the plurality of a society is inevitable because it is sunnatullah (laws of Allah/ destiny). Therefore, to deal with the plurality of a society it is important we adopt the right attitude by reading and understanding correctly and comprehensively of the religion of Islam, both from the normative and historical perspectives. As the ummatan wasathan, Muslims are expected to be a wasith (a referee), to take the position at the center (wasathiyah) among plural communities, and to always behave wasath (fair). The plurality of a society is inevitable and must be faced. The attitude of moderation will occur if plurality is understood as a potential resource for the progress of society in general. The historical experience of Muslims has shown that the peak of the Islamic civilization can only be achieved because the plurality of the community is managed well.

The first step that must be taken to empower a plural community is the process to know each other among different community groups. This process will then open an opportunity to understand each other and recognize the advantages, disadvantages, and potential of each other. This will lead to the process of collaboration to progress together and to promote virtue. Cooperation between different community groups is needed especially for mutual advantages of each other. It takes a joint commitment of all components of society, i.e. the shared responsibility, to build a society of high civilization while fighting against underdevelopment, poverty and ignorance. The energy wasted to deal with the differences should be used to build a highly civilized community.

\section{REFERENCES}

Abdillah, Zulkifli., 2010. Kepingan-kepingan Sejarah Umat Islam. Pontianak: STAIN Pontianak Press.

Ahok, Pasifikus, dkk., 1980. Sejarah Pendidikan Daerah Kalimantan Barat. Pontianak: Depdikbud,.

Alqadrie, Syarif Ibarahim,. Komunitas Cina di Kalimantan Barat, Makalah/ Artikel Online: http://syarif-untan.tripod.com/Budaya.htm, [Diakses 06 Desember 2007].

Arena Wati,. 1989. Syair Pangeran Syarif. Bangi: Universiti Kebangsaan Malaysia. Ayoub, Mahmoud M,. 2004. The Crisis of Muslim Histor. Bandung: Mizan.

Bashier, Zakaria,. 1990. Sunshine at Madinah. Liecester: The Islamic Foundation.

Engineer, Asghar Ali,. 1999. Asal Usul dan Perkembangan Islam Analisis Pertumbuhan Sosio-Ekonomi. Yogyakarta: Insist-Pustaka Pelajar.

Hasan, Hasan Ibrahim,. 2001. Sejarah dan Kebudayaan Islam. jilid 1, Jakarta: 
Kalam Mulia.

Hasanuddin \& Kristanto, Budi,. 2001. Proses Terbentuknya Heterogenitas Etnis di Pontianak pada Abad Ke-19, Humaniora,XIII/1. Hal. 64-80.

Hitti, Philip K., 2006. History of The Arabs. Jakarta: Serambi.

Lontaan, JU., 1975. Sejarah Hukum Adat dan Adat Istiadat Kalimantan Barat, Pontianak: Pemda Tk.I Kalbar.

Madjid, Nurcholish,. 1992. Islam Doktrin dan Peradaban, Jakarta: Yayasan Wakaf Paramadina.

Mubarakfury, Syaikh Shafiyyurrahman Al-., 1997. Sirah Nabawiyah, Jakarta: Pustaka Al-Kautsar.

Muafiri, Abu Muhammad Abdul Malik bin Hisyam Al-., 2005. Sirah Nabawiyah Ibnu Hisyam (Jilid 1), Jakarta: Darul Falah.

Muljono, Slamet., 1965. Menudju Puntjak Kemegahan, Jakarta: P.N. Balai Pustaka.

Rahman, Ansar, dkk., 2000. Syarif Abdurrahman Alkadri Perspektif Sejarah Berdirinya Kota Pontianak. Pontianak: Pemerintah Kota Pontianak.

Shihab, M. Quraish., 1996. Wawasan Al-Quran Tafsir Maudhu'i atas Pelbagai Persoalan Umat. Bandung: Mizan.

Yatim, Badri., 2006. Sejarah Peradaban Islam. Jakarta: RajaGrafindo Persada. 